\title{
3. ESSENTIAL ASPECTS IN THE CREATION OF MEANS OF SCENIC EXPRESSIVITY SPECIFIC TO THE PUPPET SHOW
}

\author{
Raluca Bujoreanu Huțanu ${ }^{179}$
}

\begin{abstract}
The expressiveness of a doll can be generated by the way it is constructed and animated, by the ability of the puppet to transmit messages through the play with the doll. Through color, sound, simple and clear suggestion of the puppet's message to the spectators, the object comes to life and the puppet show becomes an artistic act. In other words, the purpose of the puppet show creator is to suggest in his representation human behavior in the most expressive ways possible - using all the means of language that he has in an original and creative way.
\end{abstract}

Key words: expressivity, originality, doll

\section{Introduction}

The term of expressivity represents a quality due to which the artist can transmit states or emotions. By means of the artistic language the state, emotion acquires expression and the means of transmission becomes expressive. In Comentarii şi delimitări în teatru ${ }^{180}$ (Comments and Restrictions in Theatre), Camil Petrescu asserts that expression has the role of objectifying the act of knowledge ${ }^{181}$. In other words, the creator uses expression in order to make the audience discover and understand the message that he/she transmits through his/her work. In the opinion of Camil Petrescu, expression can be artistic or scientific. However, people usually use a combination of the two - personal expression $^{182}$. And in the case of the artist, the expression of his/her soul experiences is set up through the incorporation of his/her theoretical and practical knowledge. Expressivity becomes a skill through which he/she can express experiences or messages for the purpose of making his/her creation understood by the audience

\section{Discussions}

The scenic concept refers implicitly to the term of stage, and, by extension, is connected to the theatre. The stage refers to a space dedicated to artistic representations and is envisaged and organised so that it meets both the needs of

\footnotetext{
179 Associate Professor PhD., "George Enescu" National University of Arts from Iaşi, Romania, email: r.m.bujoreanu@yahoo.com

${ }^{180}$ Camil Petrescu, Comentarii și delimitări în teatru, Volumul I, Fundaţia Culturală „Camil Petrescu”, București, 2006

181 "In order to be worth the function expressivity must be capable to objectify the act of knowledge" Camil Petrescu, work quoted, p. 202

182 "Normally, people's expressions in general are nor artistic, neither scientific expressions, but rather personal expressions, mixing the two types, varying depending on the individual, giving what is called the personal style." Idem, p. 203)
} 
the one performing the representation, and the ones of the one that is not on stage, namely the on-looker. The idea of stage is closely connected to the one of dramatic representation. From a technical point of view, a theatre stage is made of four main parts: forestage, stage box, backstage (back of the stage), and the substage or towage. In the stage box there is the actual stage and the superior stage or the rigging-loft/ The actual stage is the place where the representation takes place, where the performer performs his/her show and the point where the audience's attention is directed.

However, moving past the technical details, one can attribute to the scenic concept, apart from the general significance of theatre, the meaning of atmosphere as well ${ }^{183}$. In the thesis Expresie și improvizație scenică (Scenic Expression and Improvisation) ${ }^{184}$, Suzana Badian also attributes to the stage the meaning of life mirroring ${ }^{185}$. In other words, actors must know as many life situations as possible, which later on, they shall be capable of representing to the audience. Therefore, being expressive from a scenic point of view means having the skill to transmit a state, a feeling, an experience lived in a suggestive manner and closer to the nature of the human behaviour.

Scenic expressivity is closely connected, on principle, to the scenic image. Marian Popescu emphasizes in his book Drumul spre Ithaca (Road to Ithaca) ${ }^{186}$ the importance that the image has in the scenic show ${ }^{187}$. He asserts that each form of art is destined to enchant a certain human sense: as music is associate with the hearing, the theatre show is firstly connected to sight. In the theatre show, apart from the backdrop and the props, the image of the actor has a special importance. Due to this , on stage, the performer must emphasize all the means that he/she has in order to create an image capable to express what the producer has proposed. Thus, bodily and vocal training are essential for accomplishing means of scenic expressivity ${ }^{188}$. The body and the voice, together with the gesture, movement, attitude, tonalities and inflexion are only a few elements that the artist on stage

\footnotetext{
183 "The stage is not only a limited space with certain technical, material details. It is an entire atmosphere." Suzana Badian, Expresie și improvizație scenică, Institutul de Artă Teatrală și Cinematografică „I. L. Caragiale”, Facultatea de Teatru, Cinematografie și T.V., București, 1977

184 Idem, p. 4

185 "The stage entails the acceptance of certain superior conventions, which entail a broader knowledge of life. It must facilitate the actor the transposition into a visual essentialised language, significantly transmissible, of the infinite complexity of life." Ibidem, p. 15

${ }^{186}$ Marian Popescu, Drumul spre Ithaca: de la text la imagine scenică, Editura Meridiane, București, 1990

187 "Through a tacit consensus it is accepted to go to theatre in order to see, although listening to in this case is as important as well and that we go to the concert in order to listen. Although this would be relatively improbable without seeing. In this latter case, however, seeing has the same importance as listening to, in the first case? Obviously not. What differentiates the quality of these two experiences is, in my opinion, the idea of scenic show. The stage is not essentially involved in the act of looking, in the concert hall, as it is in the theatre hall. [...] And for the arts of the show, certainly, the visual one (n.r. Dominant of artistic experience) is chosen as primarily." Idem p. 122

188 "It is not even necessary to emphasize how important it is for the future actor, that, in his/her artistic training, to specially focus on his/her scenic behaviour, on the plastics of his/her artistic and suggestive movement, for the accomplishment of which he/she must consciously use the possibilities of unfolding that the format of the stage can offer, as well as his/her own possibilities, attributes of his/her own body, in the interaction with partners." Suzana Badian, op.cit., pp. 3-4
} 
can influence based on the intentions of the show author and its possibilities of expression. The light, music or text, props, costumes or setting are other elements of language that complete the interpretation of the artist. The personal touch of each artist indicates the originality and specificity of a scenic image.

We understand by originality, the actor's capacity to transmit a state through his/her own means of expression ${ }^{189}$. In terms of specificity, the idea is synonymous with that of the autonomy of the puppet language. But the autonomy of the animation theatre, more exactly, the possibility of certain means, procedures and methods of representing the essence of human behaviour it is discussed not only at the level of the form of manifestation, but at the level of the essence of the message transmitted through language with puppet particularities. In this case, the autonomy of puppet language becomes an aesthetic specificity ${ }^{190}$.

\section{Results}

The idea of a show is connected to concepts such as: stage, art, drama. We can speak about dance shows, for instance, but also about syncretisms within the same show, such as ballet and opera or theatre - dance shows, etc. We can interpret the meanings of the puppet concept by relating to the definitions of the concept of puppet. Ciprian Huțanu,in his paper Teatrul de animație - Tradiție. Modernitate. Kitsch. (Animation Theatre - Tradition. Modernity. Kitsch) ${ }^{191}$ defines the concept of puppet ${ }^{192}$ as the main object of the puppet show. By means of this object, the puppeteer-actor can transmit his/her message to the audience.

In the book Magia lumii de spectacol (măști, păpuși, actori, marionete) (Magic of the Show World (Masks, Puppets, Actors, Marionettes) ${ }^{193}$, author Natalia Dănăilă clarifies this issue, synthesising the significance of the puppet concept as well. Firstly, within a puppet show, the puppet game must not be based on dialogues with lines rich in words, but, on the contrary, attitudes and silence become the main means of expression ${ }^{194}$. Consequently, the show becomes regarding puppets if the script is designed in the form of a pantomime, and the scenic game, the scenic movement of characters suggets the human behaviour ${ }^{195}$.

189 "The means of accomplishing the expressivity of a puppet are:

- originality (finding new, personal ways of expression); [...]" Anca Doina Ciobotaru, Teatrul de animație între magie și artă, Editura Princeps Edit, Iași, 2006, p. 64

190 Raluca Bujoreanu, Autonomia limbajului păpușăresc, Editura ARTES, Iași, 2008, p. 117

${ }^{191}$ Ciprian Huțanu, Teatrul de animație - Tradiție. Modernitate. Kitsch., Editura Artes, Iași, 2012

192 "If the puppet is a form of artistic expression capable of "undertaking" various personalities, equipped with an intelligent and sometimes very sophisticated mobility, meant to make available to the handler a wide variety of possibilities of expression, puppet (marionette or animation) theatre is the phenomenon that presents this form of expression to the audience in a certain game style and through various handling techniques, in an organised action and presented in the form of a representation." Idem, pp. 19-20 )

${ }^{193}$ Natalia Dănăilă, Magia lumii de spectacol (măști, păpuși, actori, marionete), Editura JUNIMEA, Iași, 2003

194 "Through their nature, puppets must always do something, must act, must carry something out on the stage; must have reactions to the surrounding world, to speak through gestures, through attitudes, through silences.. Spoken words must be counted for a puppet." Natalia Dănăilă, op.cit., Editura JUNIMEA, Iași, 2003, p. 178

195 "A good script writer firstly structures his/her work as for a pantomime. After everything is clarified from the point of view of the action, of the dramatic conflict, of a scenic situation, of the coherence of the story, the authors solves the issue of dialogues as well. They must be concise, must incite to gesture reactions, to behavioural 
In conclusion, we speak about a puppet show if we meet, first and foremost, two essential components: puppeteer artist and the puppet. The role of the puppeteer artist is to comply with the principles of the animation theatre and the elements of puppet language ${ }^{196}$, as I have emphasized in the paper Autonomia limbajului păpuşăresc (Autonomy of Puppet Language). Furthermore, we assert that the ludic has a coordinating role in the creating activity of the puppeteer ${ }^{197}$, the puppet show being designed through game ${ }^{198}$. Therefore, helped by the streamlining, styling and overmeasure of the scenic behaviour of the puppets in a puppet show, the creator transmits to its audience a message ${ }^{199}$.

Regarding the means of expressivity in the puppet show, the attention is drawn to the puppet. The expressivity of the puppet is defined through its capacity to draw the attention of the audience and to issue messages-ideas. Unlike the dramatic theatre, where the actor uses its own body to transmit as expressively as possible his message, in the puppet show, the possibility of expression of the puppet lacking the mimicry of the face is firstly created by the set decorator and/or the builder of the puppet, and then, by the handler, being helped by the set. Props, costume or sonorous background, complying with the principles of streamlining, styling and thickening ${ }^{200}$. Through streamlining one understands the capacity of the show creator to seek the most clear and significant ways to transmit a message to the audience. Complying with the principle of styling in a puppet show entails that the artist puppeteer shall represent through suggestion, in the scenic play of the puppet, human behaviour in various life situations. Finally, through the technique of thickening, the artist oversizes plastic or play elements, exaggerating the sizes or movements of the puppet and styling the ideas that he/she transmits to the audience ${ }^{201}$.

\footnotetext{
revelations. " Idem, p. 178

196 "In many cases of approach or creation of the puppet language we practically meet situations when the show, the action of actual expression of the puppeteer, cannot be considered or assessed with the puppet mark. The explanation is simple: the puppet show was not carried out based on the principle of art of the animation theatre and implicitly, both in choosing the elements of theatre language and in the achievement of the means of communication in a puppet style, the particularities of this type of language were not complied with." Raluca Bujoreanu, Autonomia limbajului păpușăresc, Editura ARTES, Iași, 2008, p. 13

197 "In the process of creation of puppet shows, the ludic is materialized in the subtle and refined game of the pupeteer artist, the ludic becomes a coordinate of the entire activity and a fundamental attribute of the creative personality." Idem, p. 121

198 "Thus, puppet shows blossom from a game and as a game." Colocvii teatrale, numărul 10, Editura Artes, Iași, 2009 , p. 29

199 "The puppet-actor, although lacking mimicry, can express, due to the streamlining, styling and oversize of movements, message sometimes having a greater impact on the audience than the person actor. (...) The show becomes thus a game of coding, when it is created, but also of decoding, when it is received." (Anca Doina Ciobotaru, op.cit, p. 48)

200 "Thus, the puppet has two possibilities of expression: one is given by the set decorator/puppet builder, and the other other by the animator. The immobility of the face, the lack of mimicry, as well as the constructive possibilities force the two to comply with three basic principles regulating the art of animation:

- streamlining;

- styling;

- thickening." Anca Doina Ciobotaru, op.cit, p. 66

201 "The thickening must be understood as having a stylistic function similar to hyperbolization in literature, meaning vis-a-vis the transmission of a message through the oversize of certain elements either visual (chromatic
} 


\section{Conclusions}

Scenic expressivity is essential in any type of show. In the puppet show, the relationship between the creativity of the artist puppeteer and his/her means of expression is found in the manner in which the puppeteer represents generalhuman issues, in forms of puppet language that he/she creates (gracious, grotesque, hilarious, etc.). The expressivity of a puppet can be generated by the manner in which it is built and animated, by the puppeteer's capacity to transmit messages through the play with the puppet. As previously specified, the other elements of scenic language also come to support the puppeteer with a plus of expressivity, in order to contour and complete the image of a puppet show in its entirety. Through colour, sound, simple and clear suggestion of the puppeteer's message to the audience, the object comes to life and the puppet show become an artistic action. In other words, the purpose of the creator of the puppet show is to suggest in his/her representation human behaviour in manners as expressive as possible - using all the language means that he/she has at his/her disposal in an original and creative manner.

\section{References}

1. Baldwin, Peter; Speaight, George, Toy Theatres of the World, Sotheby Parke Bernet Pubns, Londra, 1993

2. Badian, Suzana, Expresie și improvizație scenică, Institutul de Artă Teatrală și Cinematografică „I. L. Caragiale”, Facultatea de Teatru, Cinematografie și T.V., București, 1977

3. Bălăiţă, Aurelian, Arta teatrului de umbre, Editura Artes, Iaşi,2007

4. Brancu, Ioan, Mişcare şi expresie artistică în spectacolul de animaţie, U.N.A.T.C. Press, Bucureşti, 2005

5. Bujoreanu, Raluca, Autonomia limbajului păpușăresc, Editura ARTES, Iași, 2008

6. Bujoreanu, Raluca, Repere psihopedagogice în limbajul păpușăresc, Editura ARTES, Iași, 2008

7. Ciobotaru, Anca Doina, Teatrul de animație între magie și artă, Editura Princeps Edit, Iași, 2006

8. Dănăilă, Natalia, Magia lumii de spectacol (măşti, păpuşi, actori, marionete), Cuvânt înainte de Ştefan Oprea, Editura Junimea, Iaşi, 2003

9. Huțanu, Ciprian, Teatrul de animație - Tradiție. Modernitate. Kitsch., Editura Artes, Iaşi, 2012

10. Pepino, Cristian, Modalitatea estetică a teatrului de păpuşi (curs), U.N.A.T.C., Bucureşti, 1993

11. Petrescu, Camil, Comentarii și delimitări în teatru, Volumul I, Fundația Culturală „Camil Petrescu”, București, 2006

12. Popescu, Marian, Drumul spre Ithaca: de la text la imagine scenică, Editura Meridiane, București, 1990

emphasiz of the lines of the mouth or eyes, enlarging of a bodily segment of the puppet, depending on the character to be suggested), or by the play (gestures, exaggerated movements) or even the verbal nature." Anca Doina Ciobotaru, op.cit., p. 67 